IZA DP No. 8408

Receiving Countries' Perspectives: The Case of Sweden

Christer Gerdes

Eskil Wadensjö

August 2014

Forschungsinstitut zur Zukunft der Arbeit Institute for the Study of Labor 


\title{
Receiving Countries' Perspectives: The Case of Sweden
}

\author{
Christer Gerdes \\ SOFI, Stockholm University \\ and IZA \\ Eskil Wadensjö \\ SOFI, Stockholm University \\ and IZA
}
Discussion Paper No. 8408
August 2014

\author{
IZA \\ P.O. Box 7240 \\ 53072 Bonn \\ Germany \\ Phone: +49-228-3894-0 \\ Fax: +49-228-3894-180 \\ E-mail: iza@iza.org
}

\begin{abstract}
Any opinions expressed here are those of the author(s) and not those of IZA. Research published in this series may include views on policy, but the institute itself takes no institutional policy positions. The IZA research network is committed to the IZA Guiding Principles of Research Integrity.

The Institute for the Study of Labor (IZA) in Bonn is a local and virtual international research center and a place of communication between science, politics and business. IZA is an independent nonprofit organization supported by Deutsche Post Foundation. The center is associated with the University of Bonn and offers a stimulating research environment through its international network, workshops and conferences, data service, project support, research visits and doctoral program. IZA engages in (i) original and internationally competitive research in all fields of labor economics, (ii) development of policy concepts, and (iii) dissemination of research results and concepts to the interested public.
\end{abstract}

IZA Discussion Papers often represent preliminary work and are circulated to encourage discussion. Citation of such a paper should account for its provisional character. A revised version may be available directly from the author. 


\section{ABSTRACT}

\section{Receiving Countries' Perspectives: The Case of Sweden ${ }^{1}$}

Sweden has made its labour market more open for labour immigration since the mid1990s: becoming member of the common labour market of EES/EU in 1994, no transitional rules introduced at the enlargement of European Union in 2004 and 2007, and opening up for labour migration from non-EES/EU countries in December 2008. The changes have led to increased labour immigration. The labour immigration expanded for example after the enlargement in 2004 but not so much as in for example the United Kingdom and Ireland. Other forms of immigration have been more important. On the other hand, the migration has been rather stable in the years after the crisis in 2008. The main explanation is most likely that the recession in Sweden was only for one year, 2009, and that it was concentrated to some parts of the manufacturing industry where few migrant workers were employed. If the present EMU crisis is spreading to Sweden the result may of course be different.

JEL Classification: F22, J15, J31, J61

Keywords: immigration, wages, EU enlargement, Sweden

Corresponding author:

Eskil Wadensjö

Swedish Institute for Social Research

University of Stockholm

SE-106 91 Stockholm

Sweden

E-mail: Eskil.Wadensjo@sofi.su.se

\footnotetext{
${ }^{1}$ Chapter for the book Migration, Crisis, and Adjustment in an Enlarged $E(M) U$. The authors thank the anonymous referee as well as the editors of this volume and Per Lundborg for providing a number of suggestions that helped to improve the chapter significantly. We will also thank SIEPS for economic support making it possible to access the register data used in this chapter. We remain responsible for any mistakes still present.
} 


\section{Introduction: Sweden and labour migration}

Sweden’s immigration policy has changed drastically on several occasions over time. ${ }^{2}$ Immigration policy was very liberal from the 1860s until WW1, with no requirements regarding passports, visas or work permits, although international migration mainly involved emigration during this period in the context of Sweden, with wages lower than in neighbouring countries. The policy changed in 1914 after the start of WW1, and the controls became gradually more stringent during the war, with a work permit compulsory and difficult to attain for those who wanted to move to Sweden for work. While the immigration regulation remained after the war, the requirements for those coming from other Nordic countries were made slightly less stringent. The work permit requirement in the interwar-period was motivated by the high unemployment rate, based upon the notion that jobs should be reserved for natives.

The policy once again changed during WW2, in a less restrictive direction. Many refugees arrived to Sweden from neighbouring countries and the work permit requirement was abolished for citizens of the other Nordic countries from 1 October 1943. Following the end of the war, the Swedish economy experienced a period of very fast growth, with excess demand for labour. Employers and the governmental labour market administration (called Arbetsmarknadskommissionen up to 1948, before subsequently being reorganized and renamed Arbetsmarknadsstyrelsen) started to recruit workers from outside Sweden. The Nordic labour market was further developed, and the Common Nordic Labour Market was established in 1954 (negotiations were underway already and almost completed in 1939, yet were interrupted by the war). The period from the 1940s until the early 1970s was

\footnotetext{
${ }^{2}$ See Boguslaw (2012) for a detailed presentation of the development of the Swedish immigration policy and Wadensjö (2012) for a presentation of some of the important changes in the $20^{\text {th }}$ century.
} 
characterized by large-scale labour immigration to Sweden from the other Nordic countries, particularly Finland, as well as Southern Europe and Turkey. However, this period of easy access to the Swedish labour market ended in the late-1960s and early-1970s with the gradual introduction of a more strict work permit legislation and implementation, within which the trade unions played an active role. While the Common Nordic Labour Market remained, the wage differentials between the Nordic countries declined and Sweden became less attractive as a country of destination for those seeking jobs in neighbouring countries. $^{3}$

A period of mainly refugee and family-related migration followed from the 1970s onwards, and while this migration continues at present, labour migration has also become gradually more important again since the mid-1990s. The first of several institutional changes involved Sweden becoming a member of the EES in 1994 and EU in 1995, leading to increased migration from other EU countries to Sweden (especially Germany, the Netherlands and the United Kingdom). Moreover, a second step was the enlargement of EU in 2004, with Sweden the only country not to have introduced any transitional rules when EU gained new member states from 1 May 2004 (Ireland and the United Kingdom introduced only minor ones). ${ }^{4}$ The third step was the enlargement of EU from 1 January 2007, with some people worrying about the effects of the EU labour market enlargement on public finances. The concept of "social tourism" was launched in the debate regarding the 2004 enlargement, before the decision was taken by the Riksdag (the Swedish Parliament) that no transitional rules should be introduced. However, studies showed that the "social tourists” did not arrive, and few of the new immigrants received income transfers. These

\footnotetext{
${ }^{3}$ See Pedersen, Røed and Wadensjö (2008) for a study of the first 50 years of the Common Nordic Labour Market.

${ }^{4}$ See Doyle, Hughes and Wadensjö (2006) for the political process leading to the decision of no transitional rules.
} 
results probably contributed to a more positive attitude towards labour migration in Sweden. The same decision, namely no transitional rules, was taken when Bulgaria and Romania became members of EU from 1 January 2007.

A fourth step to a more open labour market in Sweden followed a governmental report, with a new policy regarding labour immigration from countries outside the EEA was decided on by the Riksdag in November 2008. Labour immigration from countries outside the EES was deregulated from 15 December 2008, and the only requirement for a work permit was a job offer with either a wage according to a collective agreement or on the same level as collective agreements in the industry. Unions are asked to provide their view about the working conditions, including the wage bid, before the Swedish Migration Authority decides whether to grant a work permit, but the unions cannot block the Authority's decision. This differs from the procedure during the period of mass labour immigration in the 1960s, when the unions had a veto right (yet was seldom used until the late-1960s). While a considerable expansion of labour immigration from outside EU was expected, the recession that started in the autumn of 2008 probably lead to a smaller immigration flow than would have otherwise occurred. Nonetheless, more than 10,000 work permits were granted per year during 2009-2012, while 16,543 work permits were granted in 2012. Two types of work permits dominate: highly skilled (IT-specialists, engineers, technicians, etc.), many of them from India and China, and unskilled workers, mainly from different Asian countries, but also Ukraine (typically for seasonal work in agriculture). We will return to the economic crisis and its effects on migration later in this chapter. 


\section{The development of labour migration from the new EU member countries}

\section{after $2004^{5}$}

The development of immigration from the twelve new member states is shown in table

$1{ }^{6}$ highlighting that migration from most of the EU10 countries increased from 2004

onwards. The exceptions are the two Mediterranean countries of Cyprus and Malta, with

very low emigration to Sweden both before and after 1 May 2004. The immigration from

EU10 to Sweden is dominated by migration from Poland, while the Baltic States and

Hungary are the other most important countries of origin. Many immigrants from Estonia,

Hungary and Poland had already migrated to and lived in Sweden prior to 2004, with most

of them having arrived as refugees. Indeed, the earlier migrants may have contributed to

many new migrants arriving from those countries, in a network effect.

The crisis that started in 2008 was followed by a decline in immigration from Poland, but the immigration from the Baltic States increased. The unemployment increased much more in those countries than in Sweden, and there were still job vacancies in Sweden, and particularly in the Stockholm area.

Even if migration from the EU10 countries increased from 2004 onwards, the migration from those countries to Ireland and the UK, the other two countries which in practice had no transitional rules, was much larger. Reasons for this might be that those emigrating from EU10 countries were fluent in English to some degree, as well as a higher demand for labour in those countries, especially in low-wage sectors. The unions in Sweden have

\footnotetext{
${ }^{5}$ The information in this paper is updated with four years compared to Gerdes and Wadensjö $(2008,2009)$.

${ }^{6}$ It is possible to present information on the migration flows according to country of birth, country of citizenship or country of arrival and departure. The tables presented here are based on country of birth. The differences between the different legal statuses are small. One example: The number of immigrants born in Poland was 4500 in 2011 and the number of immigrants with Polish citizenship was 4403 the same year. The corresponding numbers for emigration were 1530 for Polish born and 1395 Polish citizens.
} 
successfully implemented a high minimum wage according to agreements leading to an elimination of low wage jobs. It should be mentioned that migration also increased from those countries to those with transitional rules, such as Denmark and Germany, and also to Norway, which is a member of EES (even if not of the EU).

Immigration from Bulgaria and Romania increased between 2006 and 2007 following their entrance as members of the EU, although the increase was not very large. Migration declined in 2008 and 2009 and continued at a lower level than in 2007 in both 2010 and 2011. The drop in migration between 2007 and 2008 is most likely a result of the 2008 economic crisis, yet it may be partly a result of a number of immigrants who had already been in Sweden for some time choosing to register as living there in 2007, when they were able to receive a permit due to the EU enlargement. 
Table 1. Immigration to Sweden of people born in the new EU countries 2000-2011

\begin{tabular}{|c|c|c|c|c|c|c|c|c|c|c|c|c|c|}
\hline \multirow[t]{2}{*}{ Country } & & \multicolumn{12}{|l|}{ Year } \\
\hline & & 2000 & 2001 & 2002 & 2003 & 2004 & 2005 & 2006 & 2007 & 2008 & 2009 & 2010 & 2011 \\
\hline \multirow[t]{2}{*}{ Cyprus } & Men & 9 & 4 & 10 & 11 & 13 & 9 & 25 & 23 & 31 & 14 & 13 & 24 \\
\hline & Women & 1 & 3 & 10 & 7 & 10 & 5 & 11 & 21 & 18 & 9 & 13 & 14 \\
\hline \multirow[t]{2}{*}{ Czech R. } & Men & 34 & 38 & 58 & 50 & 47 & 55 & 85 & 109 & 166 & 101 & 83 & 101 \\
\hline & Women & 45 & 47 & 47 & 46 & 52 & 55 & 83 & 98 & 112 & 89 & 80 & 93 \\
\hline \multirow[t]{2}{*}{ Estonia } & Men & 80 & 78 & 101 & 76 & 151 & 147 & 173 & 179 & 179 & 285 & 286 & 249 \\
\hline & Women & 194 & 204 & 218 & 215 & 246 & 247 & 246 & 262 & 219 & 279 & 226 & 279 \\
\hline \multirow[t]{2}{*}{ Hungary } & Men & 73 & 87 & 111 & 75 & 97 & 125 & 255 & 423 & 567 & 470 & 435 & 390 \\
\hline & Women & 96 & 108 & 134 & 118 & 149 & 167 & 232 & 361 & 432 & 417 & 345 & 328 \\
\hline \multirow[t]{2}{*}{ Latvia } & Men & 47 & 59 & 53 & 48 & 61 & 93 & 149 & 128 & 164 & 423 & 386 & 377 \\
\hline & Women & 118 & 100 & 114 & 114 & 136 & 139 & 210 & 198 & 221 & 475 & 373 & 410 \\
\hline \multirow[t]{2}{*}{ Lithuania } & Men & 47 & 71 & 74 & 63 & 177 & 332 & 419 & 470 & 452 & 643 & 747 & 705 \\
\hline & Women & 89 & 136 & 170 & 154 & 250 & 327 & 430 & 403 & 411 & 515 & 600 & 621 \\
\hline \multirow[t]{2}{*}{ Malta } & Men & 3 & 4 & 5 & 3 & 2 & 2 & 7 & 5 & 7 & 8 & 8 & 10 \\
\hline & Women & 0 & 3 & 3 & 2 & 4 & 4 & 4 & 2 & 2 & 11 & 7 & 6 \\
\hline \multirow[t]{2}{*}{ Poland } & Men & 287 & 369 & 468 & 445 & 1155 & 1799 & 3464 & 4273 & 3881 & 2808 & 2548 & 2435 \\
\hline & Women & 471 & 561 & 727 & 698 & 1397 & 1726 & 2978 & 3344 & 3210 & 2453 & 1969 & 2065 \\
\hline \multirow[t]{2}{*}{ Slovakia } & Men & 24 & 25 & 36 & 16 & 37 & 34 & 49 & 90 & 107 & 107 & 138 & 91 \\
\hline & Women & 34 & 24 & 35 & 30 & 69 & 58 & 88 & 74 & 94 & 114 & 99 & 62 \\
\hline \multirow[t]{2}{*}{ Slovenia } & Men & 10 & 7 & 4 & 10 & 10 & 15 & 21 & 23 & 39 & 31 & 22 & 37 \\
\hline & Women & 8 & 20 & 10 & 10 & 14 & 15 & 24 & 30 & 21 & 18 & 18 & 25 \\
\hline \multirow[t]{2}{*}{ Bulgaria } & Men & 65 & 67 & 69 & 77 & 56 & 52 & 60 & 662 & 546 & 394 & 339 & 301 \\
\hline & Women & 75 & 74 & 102 & 104 & 83 & 62 & 77 & 409 & 323 & 306 & 252 & 254 \\
\hline \multirow[t]{2}{*}{ Romania } & Men & 126 & 129 & 150 & 142 & 126 & 154 & 172 & 1511 & 1441 & 1004 & 963 & 1096 \\
\hline & Women & 217 & 213 & 262 & 241 & 209 & 261 & 250 & 1121 & 1154 & 872 & 817 & 874 \\
\hline
\end{tabular}

Source: Statistics Sweden.

The corresponding figures for emigration from Sweden are presented in table 2.

Emigration is much smaller than immigration, although it increased over time, mainly as a result of a larger immigrant population. Many do not deregister when they leave Sweden with the intention of later returning, in order to avoid unnecessary complications when registering anew. This means that emigration is underestimated (and/or the registration of emigration is delayed) and the immigrant population is thus overestimated. Interestingly, Polish migration to Sweden exhibits a rather positive selectivity index, meaning that among the other receiving countries migrants from Poland to Sweden were relatively likely to return to Poland. See Chapter on Poland, THIS VOLUME. 
It is also important to acknowledge when studying the statistics that a person should only be registered as an immigrant if the intention is to stay for at least one year. This means that those coming as seasonal workers or for shorter work periods are not included in the population statistics. People come to Sweden for shorter stays for various reasons; for instance, a person who stays in Sweden for a period of less than six months only has to pay income tax at a low rate in Sweden. Rather, they have to pay income taxes in the home country, which in most cases means a lower combined tax rate. This clearly provides an incentive for those immigrating for work spells in Sweden of less than six months (less than 180 days).

A rather common phenomenon is the employment of so-called posted workers, who work in Sweden yet are employed by an employer in another country, often one of the new EU member countries. ${ }^{7}$ This is more common in some other countries such as Norway.

\footnotetext{
${ }^{7}$ See OECD (2011).
} 
Table 2. Emigration from Sweden of people born in the new EU countries 2000-2011

\begin{tabular}{|c|c|c|c|c|c|c|c|c|c|c|c|c|c|}
\hline \multirow[t]{2}{*}{ Country } & & \multicolumn{12}{|l|}{ Year } \\
\hline & & 2000 & 2001 & 2002 & 2003 & 2004 & 2005 & 2006 & 2007 & 2008 & 2009 & 2010 & 2011 \\
\hline \multirow[t]{2}{*}{ Cyprus } & Men & 19 & 12 & 12 & 14 & 10 & 12 & 11 & 15 & 6 & 10 & 6 & 12 \\
\hline & Women & 6 & 2 & 3 & 8 & 5 & 6 & 7 & 8 & 2 & 2 & 7 & 4 \\
\hline \multirow[t]{2}{*}{ Czech R. } & Men & 7 & 8 & 15 & 18 & 31 & 29 & 27 & 33 & 41 & 20 & 22 & 75 \\
\hline & Women & 8 & 14 & 17 & 17 & 23 & 26 & 24 & 32 & 29 & 23 & 29 & 31 \\
\hline \multirow[t]{2}{*}{ Estonia } & Men & 23 & 31 & 27 & 36 & 50 & 54 & 49 & 56 & 73 & 49 & 95 & 87 \\
\hline & Women & 27 & 34 & 45 & 39 & 58 & 70 & 76 & 95 & 64 & 52 & 82 & 102 \\
\hline \multirow[t]{2}{*}{ Hungary } & Men & 89 & 55 & 74 & 66 & 84 & 88 & 93 & 114 & 128 & 115 & 181 & 216 \\
\hline & Women & 66 & 67 & 74 & 81 & 81 & 79 & 84 & 100 & 97 & 84 & 151 & 167 \\
\hline \multirow[t]{2}{*}{ Latvia } & Men & 10 & 27 & 20 & 21 & 19 & 22 & 29 & 46 & 47 & 46 & 65 & 61 \\
\hline & Women & 10 & 18 & 16 & 24 & 23 & 22 & 33 & 63 & 55 & 27 & 79 & 64 \\
\hline \multirow[t]{2}{*}{ Lithuania } & Men & 8 & 30 & 12 & 19 & 26 & 20 & 41 & 63 & 91 & 72 & 102 & 119 \\
\hline & Women & 7 & 13 & 3 & 28 & 29 & 16 & 49 & 58 & 60 & 49 & 70 & 96 \\
\hline \multirow[t]{2}{*}{ Malta } & Men & 0 & 1 & 1 & 4 & 1 & 1 & 4 & 3 & 2 & 2 & 8 & 6 \\
\hline & Women & 2 & 3 & 2 & 0 & 0 & 2 & 7 & 1 & 2 & 2 & 2 & 5 \\
\hline \multirow[t]{2}{*}{ Poland } & Men & 100 & 117 & 103 & 131 & 159 & 182 & 245 & 454 & 637 & 731 & 842 & 946 \\
\hline & Women & 143 & 143 & 148 & 200 & 192 & 252 & 322 & 385 & 472 & 482 & 589 & 584 \\
\hline \multirow[t]{2}{*}{ Slovakia } & Men & 1 & 7 & 4 & 5 & 9 & 8 & 14 & 12 & 32 & 33 & 45 & 56 \\
\hline & Women & 0 & 8 & 5 & 6 & 10 & 12 & 17 & 26 & 30 & 34 & 37 & 48 \\
\hline \multirow[t]{2}{*}{ Slovenia } & Men & 2 & 2 & 2 & 6 & 3 & 4 & 8 & 4 & 8 & 7 & 10 & 19 \\
\hline & Women & 3 & 4 & 2 & 1 & 3 & 7 & 7 & 9 & 7 & 13 & 9 & 6 \\
\hline \multirow{2}{*}{ Bulgaria } & Men & 19 & 20 & 19 & 32 & 23 & 18 & 32 & 47 & 96 & 100 & 100 & 135 \\
\hline & Women & 19 & 18 & 12 & 34 & 24 & 16 & 28 & 48 & 64 & 53 & 70 & 89 \\
\hline \multirow[t]{2}{*}{ Romania } & Men & 42 & 41 & 53 & 51 & 65 & 59 & 87 & 146 & 225 & 354 & 290 & 388 \\
\hline & Women & 44 & 55 & 66 & 69 & 61 & 59 & 89 & 96 & 160 & 251 & 208 & 247 \\
\hline
\end{tabular}

Source: Statistics Sweden.

Immigration numbers larger than emigration leads to an increased immigrant

population. As shown in table 3, many immigrants from the new EU-member states already

lived in Sweden prior to the EU enlargement in 2004, mainly due to earlier refugee flows

from Estonia (in the 1940s), Hungary (in the 1950s) and Poland (in the 1960s and 1980s).

Many refugees also arrived from Czechoslovakia in the 1960s, although given that it has

not been possible to divide those immigrants between the Czech Republic and Slovakia

they are not included in the table. Those who were born in Poland represent the largest

group of foreign born from a EU12-country. Poland is the only EU12 country among the

top ten countries of origin in Sweden (Poland is number three after Finland and Iraq).

Second most highest number of persons from EU12 countries that arrived in Sweden come 
from Romania, with numbers of Romanians in Sweden stable up to 2007, before gradually increasing after Romania became an EU member in 2007.

Table 3. Immigrants living in Sweden who were born in one of the new EU countries 2000-2011

\begin{tabular}{|c|c|c|c|c|c|c|c|c|c|c|c|c|c|}
\hline \multirow[t]{2}{*}{ Country } & & \multicolumn{12}{|l|}{ Year } \\
\hline & & 2000 & 2001 & 2002 & 2003 & 2004 & 2005 & 2006 & 2007 & 2008 & 2009 & 2010 & 2011 \\
\hline \multirow[t]{2}{*}{ Cyprus } & Men & 285 & 276 & 274 & 269 & 270 & 267 & 278 & 285 & 309 & 311 & 316 & 326 \\
\hline & Women & 168 & 169 & 175 & 174 & 179 & 177 & 181 & 193 & 209 & 216 & 222 & 232 \\
\hline \multirow[t]{2}{*}{ Czech R. } & Men & 110 & 141 & 184 & 217 & 234 & 260 & 317 & 393 & 517 & 578 & 623 & 647 \\
\hline & Women & 211 & 243 & 275 & 305 & 335 & 362 & 419 & 487 & 570 & 621 & 651 & 714 \\
\hline \multirow[t]{2}{*}{ Estonia } & Men & 4417 & 4310 & 4240 & 4130 & 4065 & 4014 & 3979 & 3938 & 3904 & 4012 & 4062 & 4082 \\
\hline & Women & 5836 & 5842 & 5839 & 5834 & 5855 & 5856 & 5841 & 5862 & 5859 & 5930 & 5948 & 6250 \\
\hline \multirow[t]{2}{*}{ Hungary } & Men & 7192 & 7126 & 7052 & 6947 & 6833 & 6757 & 6798 & 6979 & 7303 & 7545 & 7656 & 7705 \\
\hline & Women & 6935 & 6901 & 6882 & 6847 & 6839 & 6843 & 6913 & 7078 & 7321 & 7574 & 7683 & 7736 \\
\hline \multirow[t]{2}{*}{ Latvia } & Men & 930 & 928 & 930 & 933 & 951 & 991 & 1085 & 1146 & 1235 & 1588 & 1890 & 2181 \\
\hline & Women & 1375 & 1421 & 1491 & 1549 & 1630 & 1724 & 1869 & 1976 & 2109 & 2528 & 2796 & 3123 \\
\hline \multirow[t]{2}{*}{ Lithuania } & Men & 319 & 356 & 417 & 456 & 600 & 912 & 1290 & 1696 & 2058 & 2626 & 3268 & 3849 \\
\hline & Women & 466 & 583 & 753 & 878 & 1094 & 1403 & 1782 & 2129 & 3479 & 2946 & 3467 & 3987 \\
\hline \multirow[t]{2}{*}{ Malta } & Men & 46 & 49 & 53 & 52 & 53 & 54 & 57 & 59 & 64 & 70 & 70 & 74 \\
\hline & Women & 41 & 41 & 42 & 44 & 48 & 50 & 47 & 47 & 47 & 56 & 60 & 61 \\
\hline \multirow[t]{2}{*}{ Poland } & Men & 13814 & 13951 & 14170 & 14354 & 15227 & 16698 & 19788 & 23472 & 26588 & 28532 & 30094 & 31449 \\
\hline & Women & 26309 & 26555 & 26949 & 27254 & 28245 & 29505 & 31955 & 34708 & 37234 & 38986 & 40159 & 41416 \\
\hline \multirow[t]{2}{*}{ Slovakia } & Men & 84 & 101 & 132 & 143 & 171 & 197 & 233 & 310 & 384 & 458 & 551 & 587 \\
\hline & Women & 159 & 175 & 206 & 231 & 292 & 339 & 411 & 457 & 520 & 600 & 662 & 675 \\
\hline \multirow[t]{2}{*}{ Slovenia } & Men & 368 & 383 & 386 & 393 & 405 & 421 & 438 & 456 & 486 & 505 & 517 & 533 \\
\hline & Women & 315 & 343 & 357 & 372 & 387 & 400 & 419 & 439 & 452 & 457 & 466 & 486 \\
\hline \multirow[t]{2}{*}{ Bulgaria } & Men & 1674 & 1718 & 1756 & 1794 & 1817 & 1838 & 1860 & 2466 & 2915 & 3209 & 3447 & 3597 \\
\hline & Women & 1834 & 1887 & 1968 & 2031 & 2084 & 2124 & 2161 & 2515 & 2771 & 3022 & 3205 & 3365 \\
\hline \multirow[t]{2}{*}{ Romania } & Men & 5359 & 5418 & 5486 & 5532 & 5556 & 5607 & 5655 & 6979 & 8171 & 8776 & 9415 & 10104 \\
\hline & Women & 6417 & 6536 & 6686 & 6811 & 6980 & 7141 & 7255 & 8235 & 9181 & 9756 & 10326 & 10912 \\
\hline
\end{tabular}

Source: Statistics Sweden.

The decline in the first years after the enlargement and subsequent slow growth of the number of people born in Estonia in spite of the rather large emigration from this country to Sweden is due to the refugees who arrived in Sweden at the end of WW2 now being old, and therefore the mortality is high. 
Most of the migrants coming from the EU12 countries are in their twenties, with many arriving just after completing secondary or tertiary education. This means that the new migrants from those countries who are employed on average have a rather high education, higher than that of the employed who were born in Sweden. The migrants from the Baltic States more commonly have a higher education compared to most other groups in the Swedish labour market (see table 4 for details).

Only a few natives and immigrants have a very low education, i.e. primary school less than nine years. Nine (or ten) years of education as the highest level is more common among natives than immigrants, which is explained by differences in the age distribution (i.e. natives are older). On the other hand, immigrants more commonly have higher education.

Note that information on education is missing for a larger share of immigrants than for natives, particularly in respect of those who have only been in Sweden a short time. It takes some time for Statistics Sweden to gain information on education from the immigrants. Statistics Sweden sends out a schedule to all new immigrants asking questions regarding their education once a year, but not all answer and return the schedule. Information on education received by various authorities such as the Labour Market Administration are sent to Statistics Sweden, and thus the missing information share is gradually reduced; however, there remains a problem with data availability on education, especially regarding those who have recently arrived in Sweden. 
Table 4. Distribution of people born in one of the new member states and Sweden according to education in 2010; per cent; only those employed included

\begin{tabular}{lllllllll}
\hline Country & \multicolumn{2}{l}{ Education } & \multicolumn{7}{l}{ All } \\
\cline { 2 - 8 } & 1 & 2 & 3 & 4 & 5 & 6 & 9 & 100 \\
\hline Cyprus & 2 & 6 & 40 & 6 & 35 & 3 & 9 & 100 \\
Czech R. & 1 & 2 & 21 & 5 & 45 & 6 & 17 & 100 \\
Estonia & 1 & 5 & 30 & 7 & 45 & 3 & 10 & 100 \\
Hungary & 2 & 4 & 43 & 6 & 38 & 3 & 4 & 100 \\
Latvia & 1 & 5 & 25 & 6 & 46 & 3 & 15 & 100 \\
Lithuania & 1 & 5 & 24 & 5 & 41 & 3 & 20 & 100 \\
Malta & 8 & 10 & 42 & 8 & 28 & 2 & 2 & 100 \\
Poland & 2 & 4 & 42 & 5 & 34 & 2 & 10 & 100 \\
Slovakia & 2 & 2 & 26 & 3 & 46 & 10 & 11 & 100 \\
Slovenia & 5 & 8 & 48 & 7 & 26 & 1 & 3 & 100 \\
\hline Bulgaria & 4 & 4 & 37 & 4 & 40 & 3 & 8 & 100 \\
\hline Romania & 2 & 5 & 39 & 6 & 41 & 3 & 5 & 100 \\
\hline EU12 & 2 & 4 & 40 & 5 & 37 & 2 & 9 & 100 \\
Sweden & 2 & 9 & 51 & 7 & 31 & 1 & 1 & \\
\hline
\end{tabular}

Notes: Educational classification; 1 primary school less than 9 years, 2 primary school 9(10) years, 3 secondary school, 4 higher education less than two years, 5 higher education two years or more, 6 postgraduate education, 9 missing information.

Source: SIEPS database.

3. The labour market situation of labour migrants from the new EU-member countries

The data on employment rates for immigrants is somewhat misleading given that many of those who have emigrated from Sweden are still registered as living there, as can be identified by the fact that many of those who are not employed and do not receive a labour income also do not receive any form of transfer income. ${ }^{8}$ Accordingly, using register data on employment leads to an underestimation of the employment rate. Therefore, here we only provide information on the labour market situation of those who are employed.

The working hours are more or less the same for natives and those born in EU10countries; 140.2 hours per month for natives and 138.1 for those born in EU12 countries.

\footnotetext{
${ }^{8}$ Some may live in Sweden and work in non-registered employment, but the number of persons for which information on both employment and income transfers is missing is too large for this to be the main explanation.
} 
While there are some problems in the statistics regarding the number of hours worked at full time, such problems should be more or less the same for all groups. Men work more hours on average than women, although this difference is not very large, indicating that even if part-time work is more common among women than men, women are most often working long part-time. The hours worked are 146.1 hours for native men per month and 145.1 for EU12-born men, as well as 135.7 hours for native born women and 134.8 hours for EU12-born women.

Table 5 shows that monthly wages of full-time work are more or less the same for immigrants and natives. As previously mentioned, those born in EU12 countries are more educated than those born in Sweden. Estimations of Mincer wage equations (with age, gender, country of birth and education as explanatory variables) show that the immigrants have slightly lower wages than natives, albeit with rather small differences. For all EU12 countries taken together, the wage is 5.7 per cent lower for men and 6.3 per cent lower for women in 2010 for whose who have arrived 2000-2010, when controlling for age and education. If dummies are included for each country, we find that the estimates differ between countries. For men, the largest negative effects in 2010 are found for Romania and Bulgaria (10.5 and 11.5 per cent respectively), and for Lithuania (10.9 per cent) in the case of women for all who have migrated from these countries. These wage differences may be due to over-education or low seniority at the workplace, although it is not possible to observe this latter aspect in the available data. 
Table 5. Monthly wage (for those working less than full-time the wage is recalculated to full-time wage) among those born in one of the new member states and Sweden aged 16-64 in 2010; in thousands SEK

\begin{tabular}{llll}
\hline Country & \multicolumn{3}{l}{} \\
\cline { 2 - 4 } & Men & Women & All \\
\hline Cyprus & 35.3 & 28.9 & 32.4 \\
Czech R. & 33.9 & 28.9 & 30.9 \\
Estonia & 33.8 & 25.5 & 26.9 \\
Hungary & 33.9 & 28.5 & 30.6 \\
Latvia & 32.9 & 25.8 & 27.3 \\
Lithuania & 32.0 & 24.7 & 26.7 \\
Malta & 31.7 & 25.2 & 28.2 \\
Poland & 31.3 & 26.0 & 27.5 \\
Slovakia & 36.7 & 30.1 & 32.2 \\
Slovenia & 27.9 & 25.2 & 26.3 \\
\hline Bulgaria & 28.8 & 26.4 & 27.2 \\
\hline Romania & 29.8 & 26.6 & 27.7 \\
\hline EU12 & 31.4 & 26.4 & 27.9 \\
Sweden & 31.9 & 25.9 & 28.4 \\
\hline
\end{tabular}

Notes: Only those employed are included. There are immigrants who have arrived from the areas of the present states Estonia, Latvia, Lithuania and Slovenia who are registered as immigrants from Soviet Union and Yugoslavia. It has not been possible to separate those from others registered as immigrants from Soviet Union and Yugoslavia.

Source: SIEPS database.

It is perhaps surprising that immigrants from the EU12 countries have more or less the same distribution across industries as natives (see table 6). The main exception is a small immigrant overrepresentation in construction and the health sector, as well as an underrepresentation in public administration. Comparing immigrants from different EU12countries,we find that those born in Lithuania and Poland are overrepresented in construction, while those who were born Lithuania are also much overrepresented in agriculture (working in the southern part of Sweden). Naturally, there may also be differences within sectors, which are not possible to detect at this level of aggregation. 
Table 6. Distribution of people born in one of the new member states and Sweden according to industry in 2010; per cent

\begin{tabular}{|c|c|c|c|c|c|c|c|c|c|c|c|c|}
\hline \multirow[t]{2}{*}{ Country } & \multicolumn{12}{|c|}{ Industry } \\
\hline & 0 & 1 & 2 & 3 & 4 & 5 & 6 & 7 & 8 & 9 & 10 & All \\
\hline Cyprus & 1 & 0 & 8 & 0 & 3 & 14 & 13 & 15 & 30 & 11 & 6 & 100 \\
\hline Czech R. & 2 & 4 & 14 & 0 & 5 & 12 & 18 & 11 & 19 & 12 & 3 & 100 \\
\hline Estonia & 1 & 2 & 8 & 0 & 9 & 17 & 19 & 10 & 19 & 11 & 3 & 100 \\
\hline Hungary & 1 & 0 & 13 & 1 & 6 & 17 & 17 & 12 & 22 & 8 & 4 & 100 \\
\hline Latvia & 2 & 6 & 8 & 0 & 11 & 14 & 21 & 8 & 15 & 12 & 3 & 100 \\
\hline Lithuania & 1 & 13 & 9 & 0 & 18 & 12 & 17 & 6 & 12 & 9 & 2 & 100 \\
\hline Malta & 0 & 0 & 20 & 0 & 2 & 13 & 18 & 13 & 10 & 23 & 0 & 100 \\
\hline Poland & 1 & 2 & 12 & 0 & 14 & 14 & 18 & 8 & 19 & 8 & 3 & 100 \\
\hline Slovakia & 1 & 2 & 14 & 0 & 5 & 12 & 13 & 14 & 27 & 10 & 2 & 100 \\
\hline Slovenia & 1 & 0 & 20 & 0 & 5 & 19 & 19 & 8 & 16 & 7 & 4 & 100 \\
\hline Bulgaria & 1 & 1 & 11 & 0 & 6 & 16 & 17 & 11 & 17 & 16 & 3 & 100 \\
\hline Romania & 1 & 1 & 18 & 0 & 6 & 15 & 18 & 10 & 20 & 8 & 3 & 100 \\
\hline EU12 & 1 & 3 & 13 & 0 & 11 & 15 & 18 & 9 & 19 & 9 & 3 & 100 \\
\hline Sweden & 1 & 2 & 14 & 1 & 7 & 19 & 16 & 11 & 16 & 7 & 6 & 100 \\
\hline
\end{tabular}

Note: Industry classification; 0 not classified, 1 agriculture, forestry, fishing, 2 manufacturing, mining, 3 public utilities, 4 construction, 5 trade, communication, 6 financial services, business services, 7 education, 8 health care, 9 personal and cultural services, 10 public administration.

Source: SIEPS database.

4. The effects on the labour market and the public sector in Sweden ${ }^{9}$

The flow of migrants from the EU12 to Sweden is small compared to the total Swedish labour market, as well as the total immigration to Sweden. If anything, the effects on wages and unemployment are thus small for the labour market as a whole. Moreover, meta studies on the labour market effects of immigration have also shown small or no effects. ${ }^{10}$ The increase in labour supply, which should lead to lower wages, is counteracted by immigrants and natives being complements in the production process, or alternatively by migrationinduced capital formation or capital import. The negative wage effects are most likely found in parts of the labour market where many migrants are arriving, with those working there being "locked in” in such labour markets.

\footnotetext{
${ }^{9}$ See Wadensjö et al. (2012) for a discussion of the economic effects of EU12 immigration. For recent general surveys of the effects of immigration, see Okkerse (2008) and Pekkala Kerr and Kerr (2011).

${ }^{10}$ See Longhi et al. (2005a, 2005b, 2008).
} 
There has been renewed interest in the labour market consequences of immigration in recent years, with added focus on placing empirical estimates in the context of labour demand theory and substitutability of types of labour (Card, 2001, 2009; Borjas, 2003; Borjas et al. 2008; Manacorda et al., 2012; Ottaviano and Peri, 2012). A review of the cited studies reveals considerable disagreement concerning the magnitudes of key substitution elasticities and, therefore, the overall economic impact of immigration. Such disagreement calls for empirical studies of the immigration wage effect that build on transparent and convincing identification strategies.

Health is one sector to which many foreign born are coming (not only immigrants from EU12 countries). Of those gaining a license to be a medical doctor in Sweden in recent years, more than half received their degree outside Sweden. While some of them are Swedish born individuals who have studied abroad and return after completing their exams, others are foreign born who became employed in Sweden. One of the larger groups of new doctors completed their exams in Poland. If the inflow of medical doctors had not taken place, the wages for doctors would have been higher. ${ }^{11}$ Moreover, another likely effect would have been a political decision leading to the faster expansion of the number enrolled in medicine studies. Medical doctors have the highest wages of all occupational groups in Sweden, and thus immigration is hardly leading to people leaving this occupation for others. Furthermore, there is no unemployment among medical doctors in Sweden.

Many migrants also work as nurse aids and in old age care. It is difficult to recruit native Swedes to such jobs in the sparsely populated northern part of Sweden, while young people, and especially women, continuing to higher education and leaving for the cities at

\footnotetext{
${ }^{11}$ Per Lundborg, SULCIS, Stockholm University has a research project on this topic. His preliminary results are indicating wage effects.
} 
the same time as the population is ageing in such areas. The solution has been the recruitment of migrant women into care jobs, who alternatively become self-employed and offer their services to the municipalities. ${ }^{12}$

Migrants from EU12 countries are also overrepresented in construction, while the same discussion being valid here as for medical doctors. However, the inflow is smaller in this case compared to the size of the specific labour market, while the outflow to other occupations is larger and there is some unemployment among construction workers, albeit not very large (around 4 per cent in September 2012). The low unemployment in this sector can be partly explained by a relatively new tax deduction scheme (called ROT) when hiring people for repairing and renovating privately owned dwellings. This has prompted a large expansion of demand for people able to undertake such work, including those from Poland and the Baltic states. There have been some conflicts between unions and employers using posted workers from EU12 countries in this area. ${ }^{13}$

Resources are redistributed by the public sector through people paying taxes and receiving income transfers and public consumption. The income redistribution is mainly transferred from those of an active age to those who are young or old, from those of an active age who are employed to those of an active age who are out of work, and from those with high labour incomes to those with low labour incomes. The migrants from EU12 countries are of active age, are employed (or at least to a low extent receiving income transfers when out of work), and do not have low incomes on average when employed. Accordingly, this means that the redistribution is from the labour migrants to the rest of the population. Prior to the enlargement in 2004, there were worries that the immigrants from

\footnotetext{
${ }^{12}$ See Hedberg and Pettersson (2012).

${ }^{13}$ There is not any study of the wage effect of immigration for the construction sector in Sweden, but it is not unlikely that there is a negative wage effect as is found in Norway. See Bratsberg and Raaum (2012)
} 
EU12 countries would be overrepresented in the income transfer programs; however, this has not been the case. The migrants have been underrepresented in those programs, which should not be considered surprising given that there is a waiting period in several of the programs prior to a person becoming eligible for compensation.

5. The effects of the crisis on migration

The economic crisis that started in 2008 only lasted for a short period in Sweden. The GDP decline was 0.6 per cent in 2008 and 5.0 per cent in 2009, when the export industry lost many of its customers and laid off workers or let them work on a short-term basis, particularly in the western part of the country. However, the economy swiftly recovered and GDP increased by 6.6 percent in 2010 and 3.9 per cent in 2011, and increased also 2012. Employment has increased during recent years, although the unemployment rate remains higher than before the crisis started in 2008.

Labour immigration declined somewhat in 2008, but has subsequently increased slightly. Moreover, other forms of immigration, such as refugee immigration and that of family members of those already living in Sweden have increased even more. In fact, Sweden is the European country accepting the most refugees relative to its population size. $^{14}$

Immigration from EU12 countries is around the same as before the crisis, but labour immigration from countries outside the EU has increased. The number of non-EU nationals gaining a work permit was 16,543 in 2012, compared to 14,722 in 2011 and 13,612 in 2010. The main countries gaining work permits in 2012 were Thailand (5,784, mainly

\footnotetext{
${ }^{14}$ See OECD (2011).
} 
seasonal workers), India (2,725, IT specialists) and China (888, both skilled and unskilled), followed by Turkey, Iran, Ukraine, Syria, Pakistan, the United States and Iraq. The current crisis in Syria has prompted an increase of both its labour migrants and refugees.

6. An evaluation of the experiences of the post-enlargement migration

Sweden is experiencing a period of economic growth at present, even if it is slowing down due to a decline in demand from other European countries. As long as the Swedish economy is growing, there will likely be an increased labour migration from the new EU member states and other countries to Sweden. Politically (in Parliament and also public opinion), there is a strong support for a labour market open for labour immigrants.

However, some problems related to labour migration have been the focus of political debate, having already led to some policy changes, and indeed may lead to further changes of the immigration policy. We will mention here some of these problems.

The working conditions of (summer) seasonal workers from countries outside the EU/EEA have been much discussed during the last three years. Many did not receive pay for their work due to bankruptcies, or received only very low pay. This has led to the regulation for companies from outside the EU/EEA hiring seasonal workers to be registered in Sweden and having to leave a bank guarantee for their wages. This had prompted an expansion of companies of the same type, but rather with employees and employers from EU/EEA countries, and with the same problems as a result.

The conditions of those employed by temporary work agencies in other EU countries, especially Poland, yet working in Sweden, has also been debated. 
There have been some examples of companies who have two different wage agreements with the foreign workers they employ: one to show to the Migration Authority to gain the work permit and a lower one that states the actual pay.

Proposals have been put forward to maintain the present rules yet strengthen the control of the rules actually being followed. The minister of Immigration stated in Parliament in February 2013 that he will put forward a proposal to the Parliament to provide the Migration Authority with more resources and a mandate to control the agreements for workers coming from outside the EU/EES. It was put forward in April 2014 (Regeringens Proposition 2013/14: 227). It will lead to legal changes valid from autumn 2014. 


\section{References}

Boguslaw, Julia (2012), Svensk invandringspolitik under 500 år, Studentlitteratur, Lund. Borjas, George (2003), “The labor demand curve is downward sloping: Reexamining the impact of immigration on the labor market”, Quarterly Journal of Economics, 118(4), pp. 1737-1744.

Borjas, George, Jeffrey Grogger and Gordon H. Hanson (2008), “Imperfect substitution between immigrants and natives: A reappraisal”, NBER WP 13887.

Bratsberg, Bernt and Oddbjørn Raaum (2012), “Immigration and Wages: Evidence from Construction”, Economic Journal, 122(565), pp. 1177-1205.

Doyle, Nicola, Gerry Hughes and Eskil Wadensjö (2006), Freedom of Movement for Workers from Central and Eastern Europe. Experiences in Ireland and Sweden, Swedish Institute for European Policy Studies (SIEPS), Report 2006:5.

Card, David (2001), “Immigrant inflows, native outflows and the local labor market impacts of higher immigration”, Journal of Labor Economics, 19(1), pp. 22-64.

Card, David (2009), “Immigration and inequality”, NBER WP 14683.

Gerdes, Christer and Eskil Wadensjö (2008), “Immigrants from the New EU Member States and the Swedish Welfare State”, Swedish Institute for European Policy Studies (SIEPS), Report 2008:9.

Gerdes, Christer and Eskil Wadensjö (2009), “Post-Enlargement Migration and Labour Market Impact in Sweden”, in Martin Kahanec and Klaus F. Zimmermann (eds.), EU Labor Markets After Post-Enlargement Migration, Springer Verlag, Berlin. 
Hedberg, Charlotta and Katarina Pettersson (2012), “Disadvantage, Ethnic Niching or Pursuit of a Vision? Motives of Immigrant Women Care Entrepreneurs in the Ageing Swedish Society”, Journal of International Migration and Integration, 13(4), pp. 423-440.

Longhi, Simonetta, Peter Nijkamp and Jacques Poot (2005a), “A Meta-Analytic Assessment of the Effect of Immigration on Wages”, Journal of Economic Surveys, 19(3), pp. 451-477.

Longhi, Simonetta, Peter Nijkamp and Jacques Poot (2005b), “The Fallacy of “Job Robbing”: A Meta-Analyses of Estimates of the Effect of Immigration on Employment”, Journal of Migration and Refugee Issues, 1(4), pp. 131-152.

Longhi, Simonetta, Peter Nijkamp and Jacques Poot (2008), “Meta-Analysis of Empirical Evidence on the Labour Market Impacts of Immigration”, IZA DP 3418.

Manacorda, Marco, Alan Manning and Jonathan Wadsworth (2012), “The impact of immigration on the structure of wages: Theory and evidence from Britain”, Journal of the European Economic Association , 10(1), pp. 120-151.

OECD (2011). International Migration Outlook: SOPEMI 2011. Paris: OECD Publishing. Okkerse, Liesbet (2008), "How to measure labour market effects of immigration: a review", Journal of Economic Surveys, 22(1), pp. 1-30.

Olli Segendorf, Åsa and Tommi Teljosuo (2011), Sysselsättning för invandrare - en ESOrapport om arbetsmarknadsintegration, Rapport till Expertgruppen för studier i offentlig ekonomi 2011:5.

Ottaviano, Gainmarco I.P. and Giovanni Peri (2012), "Rethinking the effect of immigration on wages”, Journal of the European Economic Association, 10(1), pp. 152-197. 
Pedersen, Peder J., Marianne Røed, and Eskil Wadensjö (2008), The Common Nordic

Labor Market at 50, TemaNord 2008:506, Copenhagen.

Pekkala Kerr, Sari and William R. Kerr (2011), “Economic Impacts of Immigration: A

Survey”, Finnish Economic Papers, 24(1), pp. 1-32.

Wadensjö, Eskil (2012), Framtidens migration, Underlagsrapport 5 till

Framtidskommissionen, Statsrådsberedningen, Stockholm.

Wadensjö, Eskil, Martin Ruhs and Aleksandra Wójcicka (2012), Labour Migration: What’s in it for us? Experiences from Sweden, the UK and Poland, FORES, Stockholm. 
Appendix. Data on migration flows - some problems

Knowledge about migration and its effects demands statistical information of a high quality. However, there are some problems in this respect, as detailed below.

- There is underreporting (or late reporting) of the emigration of immigrants, which leads to the migrant population being overestimated and the employment rates underestimated. The most common likely explanation for the underreporting of emigration is a lack of information on how to do it or simply forgetting to do it. However, there may also be other explanations.

- Another problem is that only those staying at least one year (or intending to stay one year) should be registered in the register of the Swedish population and thereby included in the statistics. Those who stay for at least three months are registered by the tax authority and are given a special “coordination number”. When sent to Statistics Sweden, this information is not combined with information on the country of origin or citizenship.

- Some foreign workers are arriving as tourists and staying in Sweden for less than three months and thus are not included in any of the registers.

- Another group for which we lack information is those who work in Sweden on a temporary basis for companies based in another EU country. 